\title{
Deuterium depletion inhibits lung cancer cell growth and migration in vitro and results in severalfold increase of median survival time of non-small cell lung cancer patients receiving conventional therapy
}

\author{
Gábor Somlyai 1,*, Beáta Zs. Kovács, Ildikó Somlyai', András Papp², Lajos I. Nagy³ and László G. Puskás ${ }^{3}$ \\ ${ }^{1}$ HYD LLC for Cancer Research and Drug Development, Budapest, Hungary \\ ${ }^{2}$ Department of Public Health, Faculty of Medicine, University of Szeged, Szeged, Hungary \\ ${ }^{3}$ AVIDIN Ltd, Szeged, Hungary
}

\begin{abstract}
Non-small cell lung cancer (NSCLC) is the most common type of lung cancer, accounting for $84 \%$ of all lung cancer diagnoses. In advanced NSCLC, including adenocarcinoma and squamous cell carcinoma, median survival time (MST) rarely exceeds 10-12 months. Reduced deuterium (D) concentration in water of tissue culture media and in drinking water for humans has shown a strong anticancer effect in previous investigations. In the present study, 1 parts per million ( $\mathrm{ppm}$ ) decrease of D-concentration every 8 hours resulted in reduced growth rate of the A459 lung cancer cell line in vitro, and the cell migration was also dose-dependently reduced. Retrospective study of 183 NSCLC patients consuming commercially available deuterium-depleted water (DDW) revealed a severalfold increase of MST, which was 149 months for 19 patients and 40 months for 110 patients, who started DDW-consumption at early or advanced stage, respectively. Interestingly, MST showed a significant difference by gender (107 months in females and 41.2 months in males). Application of DDW in combination with surgery plus other conventional therapies (68 patients) gave 149 months MST, while for DDW combined with chemotherapy only (48 patients) MST was 43.7 months. The present results support earlier data that integration of D-depletion to conventional therapies increases the efficacy of therapy, reduces relapse rate and increases MST.
\end{abstract}

Keywords: deuterium depletion; deuterium-depleted water; lung cancer; non-small cell lung cancer; NSCLC; A459 cell line

\section{Introduction}

In the last century, carcinoma of the lung has progressed from an uncommon and obscure disease to the most common malignancy in the world and the most common cause of death from cancer. In 2018, there were 121,680 new cases of lung cancer among men and 112,350 among women in the US, equivalent of 641 lung cancers diagnosed per day [1]. Despite all efforts at management, and recently registered more efficient new drugs [2], the prognosis of advanced lung cancer in stage IV, including both small-cell lung cancer (SCLC) and non-small-cell lung cancer patients (NSCLC) is extremely poor, with a median survival time (MST) of 8-12 months [3-5]. NSCLC is the most common type of lung cancer, accounting for $84 \%$ of all lung cancer diagnoses (Cancer. Net). In advanced NSCLC, such as adenocarcinoma and squamous cell carcinoma, the MST rarely exceeds 10-12 months; and adjuvant therapies can extend the survival of these patients by a few months only [6]. In special cases however, a significant increase (15.4 months) in survival could be achieved in NSCLC patients who were diagnosed with epidermal growth factor receptor (EGFR) gene mutation, thanks to targeted drug development $[7,8]$.
A novel, submolecular approach to tumor cell physiology can, however, provide a better alternative form of cancer treatment. Studies investigating the possible role of naturally occurring deuterium $(16.8 \mathrm{mmol} / \mathrm{L}$ in natural waters) revealed that deuterium-depleted water (DDW) inhibited tumor cell growth in vitro and caused tumor regression in vivo [9]. The data suggest that the significantly different chemical and physical properties of hydrogen $(H)$ and deuterium (D) [10-12] and the changing

*Corresponding author: Gábor Somlyai, HYD LLC for Cancer Research and Drug Development, 1118, Budapest, Villányi út 97, Hungary, Email: gsomlyai@hyd.hu

Received 19 March 2021 Revised 25 June 2021 Accepted 9 July 2021 Published 23 July 2021

Citation: Somlyai G, Kovács BZs, Somlyai I, Papp A, Nagy LI, Puskás LG. Deuterium depletion inhibits lung cancer cell growth and migration in vitro and results in severalfold increase of median survival time of non-small cell lung cancer patients receiving conventional therapy. J Cancer Res Ther. 2021; 9(2):12-19. DOI: 10.14312/2052-4994.2021-2

Copyright: @ 2021 Somlyai G, et al. Published by NobleResearch Publishers. This is an open-access article distributed under the terms of the Creative Commons Attribution License, which permits unrestricted use, distribution and reproduction in any medium, provided the original author and source are credited. 
$\mathrm{D} / \mathrm{H}$ ratio have a high impact on cell physiology $[13,14]$. In order to investigate the possible role of $D$ in cell cycle regulation, numerous studies have been conducted on different cell lines in culture media containing DDW, which verified the determinative role of $D$ in cell signaling and tumor growth [9, 15-18]. The apoptosis-triggering effect of DDW has been demonstrated in vitro [15] and in vivo [19]. D-depletion also exerts influences on protooncogenes and tumor suppressor genes. Induction of the expression of c-Myc, Ha-ras, and p53 genes by carcinogen exposure was significantly inhibited when experimental animals were given DDW to drink [20]. Cancer cells are extremely sensitive to D-depletion, which can cause tumor necrosis induced by ROS (reactive oxygen species) [21]. Recent studies confirmed that $D$ is a natural cell growth regulator that controls mitochondrial oxidation-reduction balance [21-23]. The clinical outcome of D-depletion was investigated in prospective [24] and retrospective studies [24-26]. In four lung cancer cases with brain metastases, a remarkably long survival time was observed, which was an exceptional response of brain metastases from lung cancer [27].

Here we confirm previously published in vitro data on cell growth inhibition by deuterium depletion, applying the most advanced technology (xCELLigence RTCA system [Roche Applied Sciences]) and present a retrospective, follow-up study to show the impact of DDW-consumption on the outcome of NSCLC patients. The daily amount of fluid intake of the 183 lung cancer patients was replaced with DDW for at least 91 days, without altering the conventional treatment regimens. The primary end point of the human study was the median survival time (MST). Different subgroups were created to compare the data to historical controls.

The data indicate that the combination of D-depletion with existing conventional therapies results in a severalfold increases of MST.

\section{Materials and methods}

Production of deuterium-depleted drinking water

DDW was produced from ordinary drinking water of natural D-content (150 ppm equivalent to $16.8 \mathrm{mmol} / \mathrm{L}$ ) by fractional distillation $[25,28]$ using a GMP-conform technology. Final D-level was in the range of 38 to 25 ppm, verified by a Liquid-Water Isotope Analyser-24d (manufactured by Los Gatos Research Inc., USA) with $\pm 1 \mathrm{ppm}$ precision. For the marketed product intended for human consumption (Preventa ${ }^{\circledR}$ ), DDW was mixed with natural spring water in order to adjust the exact D concentration, and to replace minerals. In the present study, drinking water with 105, 85, 65, 45, and 25 ppm D concentration were used.

\section{Culture media and cell lines}

Two stock solutions were made up, each containing $6.68 \mathrm{~g}$ DMEM, $0.11 \mathrm{~g} \mathrm{NaHCO}_{3}, 0.01 \mathrm{~g}$ Streptomycin and $500 \mu \mathrm{l}$ Penicillin, dissolved in either distilled water or DDW that contained 24 ppm D.

These solutions were sterile filtered (Acrodisc Premium $25 \mathrm{~mm}$ Syringe Filter with $0.2 \mu \mathrm{l}$ GHP Membrane, Pall Life
Sciences, cat. P NAP-4564T) and mixed to obtain culture media with the necessary $D$ concentrations in each experiment. A549 lung cancer cells were cultivated at $37^{\circ} \mathrm{C}$, $5 \% \mathrm{CO}_{2}$.

Measurement of the inhibitory effect of gradual D-depletion on the growth of $A 549$ cells

The inhibitory effect of DDW on cell growth was studied using the label-free, real-time detection technology, xCELLigence RTCA system. The system is a microelectronic cell sensor method based on microelectrodes integrated in the bottom of the wells of a microtiter plate (96-well E-plate). Presence of the cells on top of the electrodes affects the local ionic environment, leading to an increase in the electrode impedance, which enables continuous monitoring of adhesion, proliferation, and viability of the observed cells (the more cells are attached to the electrodes, the larger is the increase in electrode impedance). The system was operated according to the instructions in the Users' Manual. The cells were seeded into wells of the 96 -well E-plate at 4,000 cells per well, cultured at $37^{\circ} \mathrm{C}$ in $5 \% \mathrm{CO}_{2}$ atmosphere, and continuously monitored. A dimensionless parameter termed Cell Index (Cl) can be derived from the relative change in measured electrical impedance [29]. Therefore, $\mathrm{Cl}$ is suitable for describing cell count and viability. Decrease in $\mathrm{Cl}$ after treating the cells with an agent in the medium indicates inhibitory effect.

Before being seeded into E-plates, the cells were starved overnight without fetal calf serum (FCS). At 24 hours after seeding, the medium was changed to test media ( $D$ at different concentrations; 150 ppm, 135 ppm, 125ppm, 115 ppm, 105 ppm, 85 ppm, 65 ppm and 40 ppm) and the cells were observed between 23 and 70 hours. The experiment was carried out in four replicates.

\section{Measurement of the effect of gradual D-depletion in the media of A549 lung cancer cells}

In this test, the A549 lung cancer cells were treated with media containing $\mathrm{D}$ at gradually decreasing concentrations, starting at $150 \mathrm{ppm}$. The medium was replaced every 8 hours with a new one of $D$ concentration reduced in the first series by 0 ppm (control) or by $5,7.5$, or 10 ppm, in altogether 8 consecutive steps. In the second series, D-level reductions were 0 ppm (control), 1 ppm, 2.5 ppm or $5 \mathrm{ppm}$. Cells were monitored real time from 30 hours to 100 hours, 24 hours after seeding them in the E-plates, CI was measured and plotted for each cell line and for each D concentration in cell media.

Measurement of the effect of D-depletion on the migration of A549 lung cancer cells

Migration of the cancer cells was measured using the cellular invasion/migration-plate (CIM Plate) in the RealTime Cell Analyzer (RTCA) system. The CIM plate is composed of an upper and a lower chamber. The upper chamber has 16 wells that are sealed at the bottom with a microporous polycarbonate membrane containing microelectrode sensor arrays integrated on its bottom surface. Cells during migration through the electrode sensor arrays affect the impedance of the electrodes that leads to a $\mathrm{Cl}$ increase. The driving force of the migration 
is the chemo attractant imbalance between the two chambers, namely that the medium in the upper chambers does not contain FCS while that in the lower chamber is supplemented with FCS.

All assays were conducted on freshly seeded cells. Cells were suspended in serum-free medium containing $D$ at a concentration of 150 ppm, 135 ppm, 120 ppm or 105 ppm and then $2 \times 10^{4}$ cells in $150 \mu \mathrm{L}$ of the medium were seeded into each upper well of the CIM plate. $\mathrm{Cl}$ was determined in real time through 80 hours.

\section{Administration of DDW}

The aim of the treatment was to reduce $D$ concentration in the patients' body by replacing the normal fluid intake with DDW, consuming 1.5-2 litres per day. The patients used it as a supplement (and not replacement) of the conventional therapies. DDW-consumption typically started with $105 \mathrm{ppm} \mathrm{D}$ and was changed to 85 ppm, 65 ppm, 45 ppm and 25 ppm every 1 to 3 months. Depending on stage of disease and response to deuterium depletion, DDW-consumption was suspended after long progressionfree interval or complete remission for 3 to 6 months, and started again for repeated 4 to 6-months' durations. Over the time, the treatment periods were shortened, although each had to be at least 3-4 months long and later the 3-6 months long breaks were prolonged (Figure 1). The duration of DDW-consumption in the follow-up population was between 91 and 3,793 days.

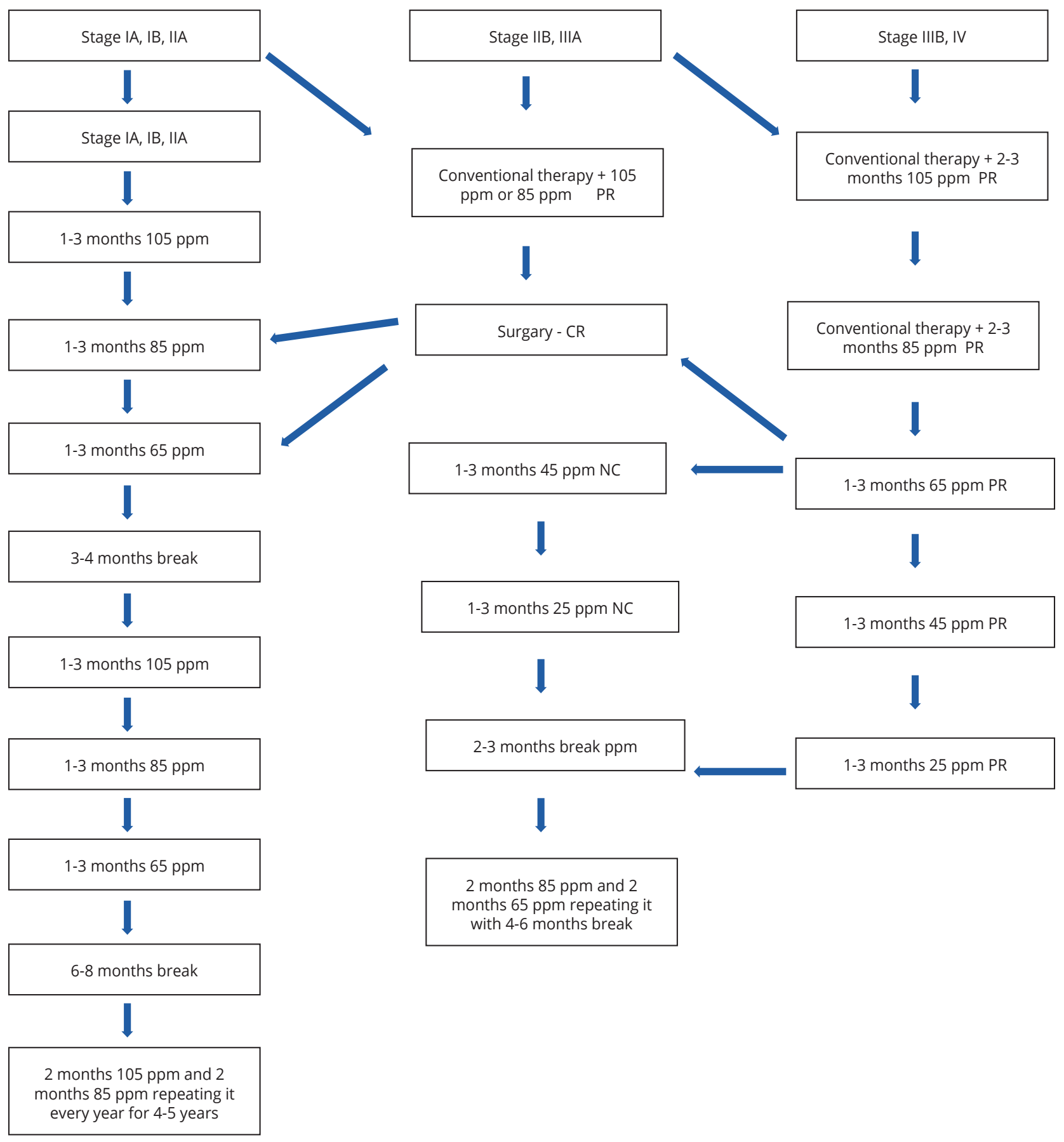

Figure 1 Consort flow diagram of the proposed application of D-depletion according to staging at diagnosis. 
The patients were continuously updated with, aware of, consented and provided access to all available information and publications regarding deuterium depletion.

\section{Data collection}

Our study had access to the data of 377 lung cancer patients consuming DDW between April 1993 and October 2019. The criteria of eligibility were histologically confirmed NSCLC tumor and duration of DDW-consumption longer than 90 days. Based on these two criteria, 183 patients (85 males and 98 females) were enrolled in the retrospective study.

The aim of the study was to investigate the effect of DDWconsumption on the outcome of NSCLC in combination with conventional therapies. The patients received the conventional forms of therapy, and underwent followup examinations, in different hospitals in Hungary. Data collection was closed in March 2020. Patient documentation was evaluated retrospectively, with survival as the only endpoint of the study.

\section{Statistical evaluation}

The primary endpoint of the study was survival, and the Kaplan-Meier method was applied to calculate survival curves. Statistical analysis was performed using MedCalc Statistical Software, Version 12.3.0. Because the study was performed retrospectively and patients started DDWconsumption at different time points after diagnosis, MST was computed both from the time of diagnosis of lung cancer and from the start of DDW-consumption. The mean difference is significant at 0.05 level.

For correlation analysis, the Pearson method was used. Variables were duration of DDW-consumption in days and survival time in days. The calculations were performed by Adware Research Ltd (Balatonfüred, Hungary).

\section{Results}

\section{Retrospective study with 183 NSCLC lung cancer patients receiving conventional therapies and consuming DDW}

Disease characteristics of 183 DDW-consuming lung cancer patients

The 183 evaluated patients were diagnosed with NSCLC before they started to consume DDW. Each patient had tumor at the start of DDW-consumption, except for 10 patients, who were operated earlier, and the tumor had been removed. Patients were in different stages at the start of DDW-consumption, and were divided to three groups (Table 1) based on TNM classification: group $A$, (stage IA, IB and stage IIA) group $B$ (stage IIB, stage IIIA) and group C (stage IIIB and stage IV) [30]. Of these 183 patients, 113 $(61.7 \%)$ had adenocarcinoma, $47(25.7 \%)$ had squamous cell carcinoma, and $23(12.6 \%)$ had mixed or uncharacterized NSCLC (Table 1). All patients underwent conventional treatments with chemotherapeutic agents, radiotherapy, surgery, targeted therapy, or their combinations.

The median age in the study population was 60 years (mean was 59.3 \pm 9.55 years). The patients started DDWconsumption at different times after diagnosis. The median length of time between diagnosis and start of DDW-consumption was 2.9 months, the mean was $9.9 \pm 18.4$ months (mean \pm SD). The broad standard deviation reflected that in some cases a couple of years elapsed until inclusion in the study, whereas other patients were enrolled after only a few months or close to diagnosis. The median duration of DDW-consumption was 20.4 months, and its cumulative duration, $2,480.5$ months (206.7 years). During the $5,740.8$ months (478.4 years) cumulative length of total follow-up (from diagnosis to the end of follow-up) 59 patients died (32.2\%). The median follow-up period from the diagnosis was 21.1 months (1.75 years), although the SD (33.8 months) of the 32.7 months average followup period indicated a wide range of values. Seven patients (3.8\%) were followed for a period longer than 10 years, and $77 \%$ of the patients were alive over a year after the diagnosis.

Table 1 Prevalence of non-small cell lung cancer tumor subtypes and disease stages in the study group by genders.

\begin{tabular}{|c|c|c|c|c|c|}
\hline Gender & $\begin{array}{l}\text { Histological subtypes } \\
\text { of tumor }\end{array}$ & $\begin{array}{l}\text { Group } \\
\text { A }\end{array}$ & $\begin{array}{l}\text { Group } \\
B\end{array}$ & $\begin{array}{l}\text { Group } \\
C\end{array}$ & All \\
\hline \multirow[t]{3}{*}{ Male } & Adenocarcinoma & 3 & 11 & 25 & 39 \\
\hline & $\begin{array}{l}\text { Squamous cell } \\
\text { carcinoma }\end{array}$ & 2 & 18 & 16 & 36 \\
\hline & Other or unknown & 1 & 1 & 8 & 10 \\
\hline \multirow[t]{3}{*}{ Female } & Adenocarcinoma & 10 & 21 & 45 & 76 \\
\hline & $\begin{array}{l}\text { Squamous cell } \\
\text { carcinoma }\end{array}$ & 1 & 2 & 8 & 11 \\
\hline & Other or unknown & 1 & 1 & 9 & 11 \\
\hline All & All subtypes & 18 & 54 & 111 & 183 \\
\hline
\end{tabular}

Note: Based on TNM classification, patients with stage IA, IB and stage IIA are collected in Group A, with stage IIB, stage IIIA are collected in Group B and with stage IIIB and stage IV are collected in Group C.

\section{Calculations of MSTs of the cancer patients}

The 183 patients consuming DDW in addition to conventional treatments showed increased MST compared to historical control (8-12 months). Two different MSTs were calculated, one from the date of diagnosis and one from the start of DDW-consumption. MST from the diagnosis was 61.9 months ( $95 \% \mathrm{Cl}: 40.3$ - 83.5), and from the start of DDW-consumption it was 48.4 months ( $95 \% \mathrm{Cl}$ : 20.9 - 75.7).

\section{Differences of MSTs in the whole cohort by gender}

There were striking differences between the two genders in the calculated MST values. Calculating from the date of diagnosis, MST was 41.2 months ( $95 \% \mathrm{Cl}: 29.4$ - 53.0) in the male and 107.0 months ( $95 \% \mathrm{Cl}: 61.3-152.8)$ in the female subgroup (significant difference, $\mathrm{p}=0.030$ ). Calculating MSTs from the date of DDW-consumption, the males' MST was 33.2 months (95\% Cl: 16.0 - 50.4), and the females' MST was 82.0 months (95\% Cl: 35.1 - 128.9); the difference was significant $(p=0.009)$ (Figure 2$)$.

It is important that 38 (34\%) male and $75(66 \%)$ female patients had adenocarcinoma; whereas $36(77 \%)$ male and $11(23 \%)$ female patients had squamous cell cancer at the start of DDW-consumption, which may explain the striking differences of MST in the cohort by gender (Table 2). 

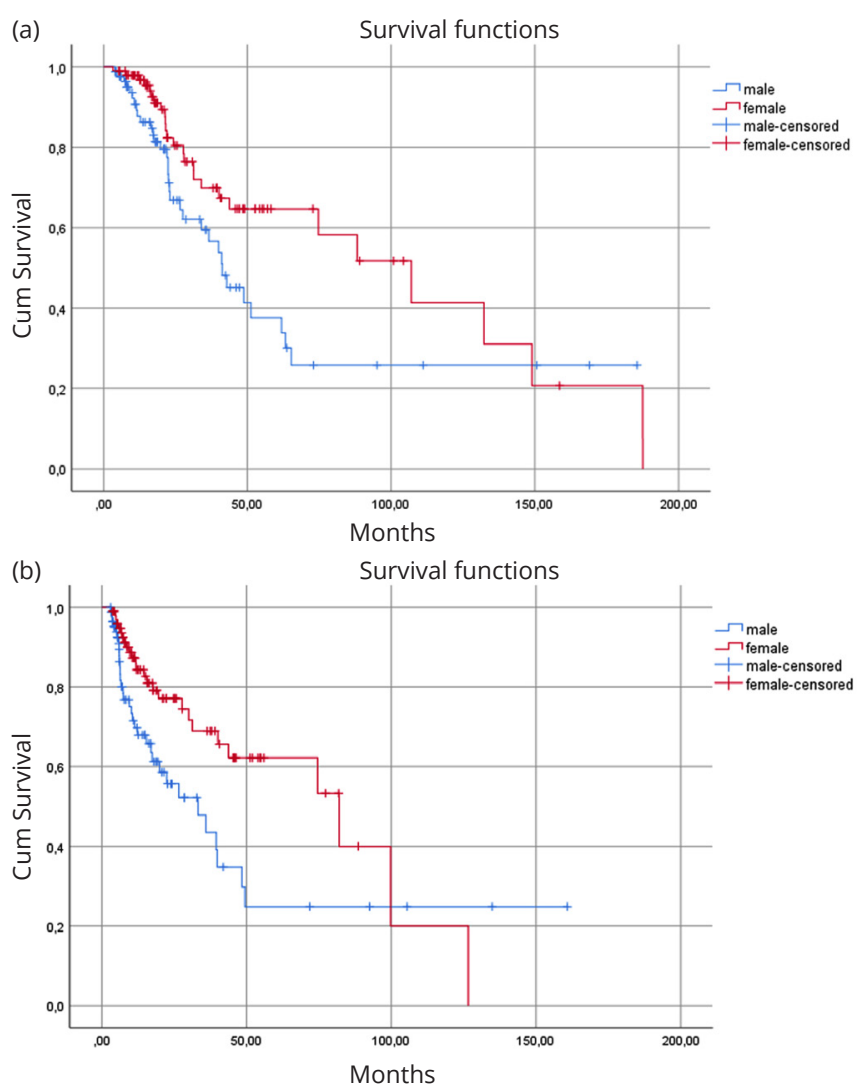

Figure 2 Kaplan-Meier graphs of survival in male and female subgroups, (a) shows survival from the diagnosis, (b) shows survival from the start of DDW-consumption.

\section{Differences of MST in the whole cohort by histology}

The data indicated that survival was strongly influenced by histology of NSCLC. Table 2 shows the MST of patients by different histology and gender.

Table 2 Median survival time (MST) data of the 183 lung cancer patients by different histology and gender for the whole cohort.

\begin{tabular}{lccc}
\hline Type of histology & $\begin{array}{c}\text { Number of } \\
\text { patients }\end{array}$ & $\begin{array}{c}\text { MST from } \\
\text { diagnosis } \\
\text { (months) }\end{array}$ & $\begin{array}{c}\text { MST from } \\
\text { start of } \\
\text { DDW } \\
\text { (months) }\end{array}$ \\
\hline Adenocarcinoma & 113 & 107.0 & 74.5 \\
Adenocarcinoma male & 38 & 51.2 & 35.9 \\
Adenocarcinoma female & 75 & 107.0 & 82.0 \\
Squamous cell carcinoma & 47 & 42.8 & 17.4 \\
Squamous cell carcinoma Male & 36 & 41.2 & 17.4 \\
Squamous cell carcinoma Female & 11 & 74.7 & $\begin{array}{c}\text { * MST not } \\
\text { avplicable } \\
\text { Avage: }\end{array}$ \\
Other or unknown & & & $35.0 *$ \\
\end{tabular}

*Due to low death rate, MST could not be calculated, and average survival is shown.

MST in the whole cohort and in the subgroups created by stages of cancer at the start of DDW-consumption

Difference between subgroups was statistically significant when calculating the MST from the diagnosis $(p=0.037)$ or from the start of DDW-consumption $(p=0.015)$ which clearly confirmed the importance of tumor diagnosis at as early stage as possible. The data also show (Table 3) that even in the worst-case scenario, in group C, the MST was severalfold longer compared to historical control [2-6].

Table 3 Summary of the data of 183 lung cancer patients by subgroups ( $\mathrm{A}$, $\mathrm{B}, \mathrm{C})$.

\begin{tabular}{lcccc}
\hline $\begin{array}{l}\text { Groups created } \\
\text { by staging }\end{array}$ & $\begin{array}{c}\text { Number of } \\
\text { patients }\end{array}$ & $\begin{array}{c}\text { MST from } \\
\text { diagnosis } \\
\text { (months) }\end{array}$ & $\begin{array}{c}\text { MST from } \\
\text { start of } \\
\text { DDW } \\
\text { (months) }\end{array}$ & $\begin{array}{c}\text { MST of } \\
\text { prospective } \\
\text { studies } \\
\text { (months) }\end{array}$ \\
\hline Whole cohort & 183 & 61.9 & 48.4 & \\
Group A & 19 & 149.0 & 126.6 & $\begin{array}{c}\text { IA, IB not } \\
\text { applicable, } \\
\text { IIA 66.0 }\end{array}$ \\
Group B & 54 & 61.9 & 48.3 & $\begin{array}{c}\text { IIB 49.0, IIIA } \\
29.0\end{array}$ \\
Group C & 110 & 40.0 & 35.9 & IIIB 14.1, IV 8.8 \\
\hline
\end{tabular}

MST in various combinations of DDW with conventional therapies

The data summarized in Table 4 confirmed that the application of DDW multiplied the MST in any combination with conventional therapies. The longest MST was achievable if the patient was operable and/or DDWconsumption started in remission or in combination with chemotherapy after surgery. In the groups where MST from diagnosis and from DDW onset was identical or minimally different, median time between the diagnosis and the start of DDW-consumption was short (2.3 months).

Table 4 Data of the whole cohort by various combination modes of DDWconsumption with conventional therapies.

\begin{tabular}{|c|c|c|c|}
\hline $\begin{array}{l}\text { Type of conventional } \\
\text { treatment }\end{array}$ & $\begin{array}{l}\text { Number } \\
\text { of } \\
\text { patients }\end{array}$ & $\begin{array}{l}\text { MST from } \\
\text { diagnosis } \\
\text { (months) }\end{array}$ & $\begin{array}{l}\text { MST from } \\
\text { start of DDW } \\
\text { (months) }\end{array}$ \\
\hline $\begin{array}{l}\text { Conventional therapies } \\
\text { but not surgery }\end{array}$ & 115 & 42.8 & 39.9 \\
\hline $\begin{array}{l}\text { Surgery and conventional } \\
\text { therapy }\end{array}$ & 68 & 149.0 & 82.0 \\
\hline Only surgery & 20 & 149.0 & 126.6 \\
\hline $\begin{array}{l}\text { Surgery and } \\
\text { chemotherapy }\end{array}$ & 19 & $\begin{array}{c}\text { *MST not } \\
\text { applicable } \\
\text { Average:144.4 }\end{array}$ & $\begin{array}{c}\text { *MST not } \\
\text { applicable } \\
\text { Average:103.7 }\end{array}$ \\
\hline $\begin{array}{l}\text { Surgery and } \\
\text { chemotherapy and } \\
\text { radiotherapy }\end{array}$ & 22 & 31.3 & 30.0 \\
\hline $\begin{array}{l}\text { Chemotherapy other than } \\
\text { cisplatin }\end{array}$ & 109 & 63.2 & 40.1 \\
\hline Cisplatin & 22 & 24.3 & $\begin{array}{c}\text { *MST not } \\
\text { applicable } \\
\text { Average: } 60.9\end{array}$ \\
\hline Only chemotherapy & 48 & 43.7 & 39.9 \\
\hline $\begin{array}{l}\text { Chemotherapy and } \\
\text { radiotherapy }\end{array}$ & 42 & 40.1 & 40.1 \\
\hline
\end{tabular}

To investigate the possible additive or synergistic effect between DDW and chemotherapeutic agents, MST of patients $(n=22)$ receiving cisplatin, or chemotherapeutic agents $(n=109)$ other than cisplatin, was evaluated. Median survival time could not be calculated for cisplatin-treated patients, only 7 of 22 died during the 42 years of cumulative 
follow-up time. Their average MST was 60.9 months (95\% Cl: 35.3 - 86.7).

The mean survival was 84.2 months, the MST of the 109 non-cisplatin-treated patients from the start of DDWconsumption was 40.1 months ( $95 \%$ Cl: 28.402 - 51.798).

Correlation between survival times and DDW-consumption in 183 lung cancer patients

Correlation between the duration of DDW-consumption and survival times calculated from the start of DDW was statistically significant $(r=0.677, p<0.001)$. Longer DDWconsumption resulted in extended survival times (Figure 3).

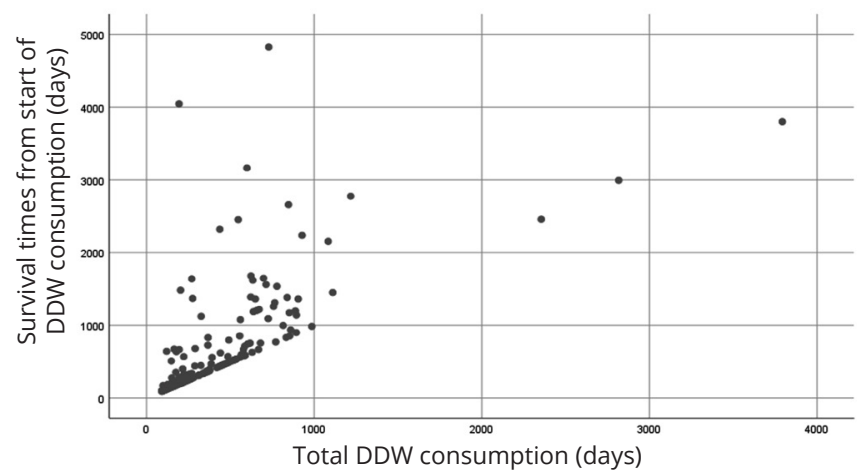

Figure 3 Calculation of survival times in the cohort by the duration of DDWconsumption.

\section{In vitro study with A549 lung cancer cells}

Deuterium depletion inhibits the growth of A549 lung cancer cells in vitro

The effect of DDW on growth of different tumor cell lines (L929, A4, MCF-7, PC-3, M14, A549) in vitro investigated with the XTT microculture tetrazolium assay has been published $[9,15,31,32]$. The accuracy of this method is not sufficient [33] to detect nuance differences that may exist between two relatively close $D$ concentrations, so that a novel technology, XCELLigence RTCA system (Roche Applied Sciences), that allows the label-free, real-time measurement of cell growth was applied. This method had the necessary accuracy to reveal the high sensitivity of cancer cells to D-depletion.

Treatment with culture media containing $155 \mathrm{ppm}$ (control), 135 ppm, 125 ppm, 115 ppm, 105 ppm, 85 ppm, $65 \mathrm{ppm}$ and $40 \mathrm{ppm} \mathrm{D}$ showed that D-depletion resulted in dose-dependently reduced cell growth, quantified by Cell Index (CI) (Figure 4).

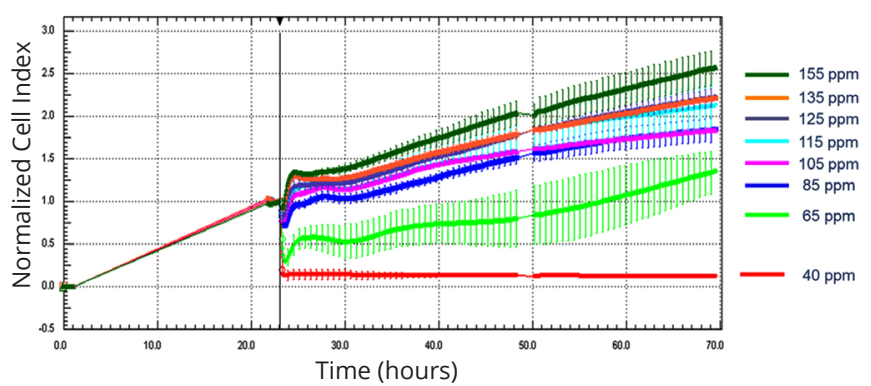

Figure 4 Effect of D-concentration on the growth rate of A549 lung cancer cell line. At 105 ppm and lower, the difference in Cl was significant. Complete inhibition of cell division was observed at $40 \mathrm{ppm}$ D-concentration.
Significant effect on $\mathrm{Cl}$ change was found in the A549 cell line with media containing $\mathrm{D}$ at $105 \mathrm{ppm}$ or less, and complete inhibition of cell division was observed at 40 ppm D-concentration.

Gradual decrease of $D$ concentration in the culture medium resulted in significantly reduced growth rate of A549 lung cancer cells

In order to investigate the effect of gradual decrease of D concentration, that occurs in the human body when normal water intake is replaced with DDW, D-level in the culture medium was lowered 8 times every 8 hours. In the first set of measurements, the decrease steps were 0 ppm (control), 5 ppm, $7.5 \mathrm{ppm}$ or $10 \mathrm{ppm}$. The $5 \mathrm{ppm}$ decrease already inhibited cell growth completely, so 7.5 ppm and 10 ppm decrease had obviously no additional effect (data not shown). In order to evaluate the lowest level of $\mathrm{D}$ concentration decrease within 8 hours exerting an inhibitory effect, the steps of concentration decrease in the second set of measurements were reduced to $0 \mathrm{ppm}$ (control), 1 ppm, 2.5 ppm and 5 ppm (Figure 5).

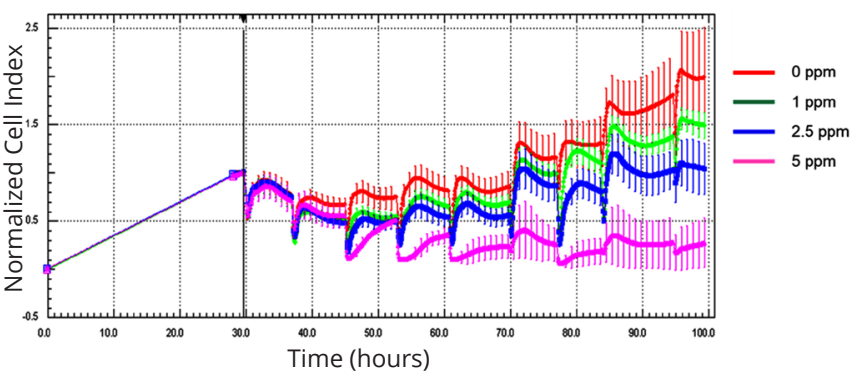

Figure 5 Effect of gradual decrease of D-concentration on A549 lung cancer cell line. D concentration was decreased by 0 ppm (control), 1 ppm, 2.5 ppm or $5 \mathrm{ppm}$ in every 8 hours. Steps of $1 \mathrm{ppm}$ or higher showed inhibitory effect.

The $\mathrm{Cl}$ value was lower in comparison to the control treatment after the second step, at 16 hours of D-depletion, with 1, 2.5, or $5 \mathrm{ppm}$. After the third step of decrease, the dose-dependence was evident and could be observed during the whole monitoring period of 70 hours.

D-depletion inhibits the migration activity of A549 lung cancer cells in dose-dependent manner

A549 lung cancer cells, freshly seeded on microporous membrane were treated with media containing $D$ at concentration of $150 \mathrm{ppm}$ (control), 135 ppm, 120 ppm or 105 ppm. Migration through the membrane into the bottom chamber of the system was forced by supplementing the lower medium with FCS. Cell migration influenced the impedance of the array-electrodes on the bottom side the membrane, leading to $\mathrm{Cl}$ increase. The lower the D concentration was in the medium applied, the lower $\mathrm{Cl}$ was detected, indicating that D-depletion proved to be effective in the inhibition of the migration activity of the tested cell line in a dose-dependent manner (Figure 6).

\section{Discussion}

It has been demonstrated in in vitro and in vivo experiments that naturally occurring deuterium plays an important role in cell growth, as well as that deuterium depletion induces apoptosis in tumor cells, resulting in partial or complete tumor regression $[9,15,19,31]$. 


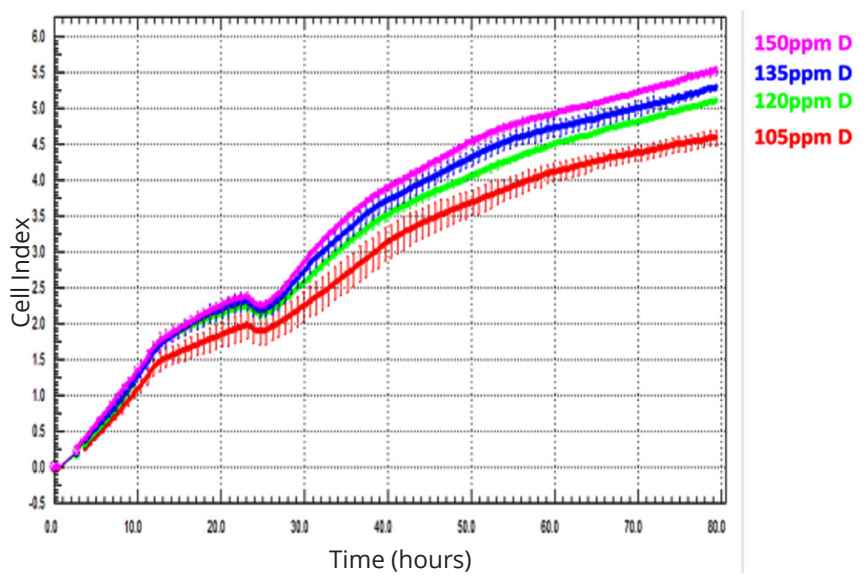

Figure 6 Effect of D-concentration on the migration rate of A549 lung cancer cell line. The A549, cells were treated with media containing D at $150 \mathrm{ppm}$ (control), 135 ppm, 120 ppm or 105 ppm concentration. With increasing depletion of $D, C l$ decreased, indicating shower migration of the cells.

To gain further information on the effect of DDW applied in combination with conventional therapies, the data of 183 NSCLC patients were evaluated retrospectively. As it is common for retrospectively collected data, the population was heterogenous regarding the stage of disease when DDW-consumption started, the time gap between diagnosis and onset of DDW-consumption, and the type of conventional therapy; but all of the 183 involved cases had histologically confirmed NSCLC tumor, except 10 which were operated earlier, and each of them consumed DDW longer than 90 days. The cumulative length of total followup (from diagnosis to the end of follow-up) was 5,740 months (478 years).

MST for the 183 patients in the present study was 61.9 months from diagnosis and 48.4 months from start of DDW-consumption, respectively, indicating a six- and fivefold increase of MST compared to historical control [1$5,7,8]$. There was a substantial difference between MST of females (82.0 months) and males (33.2 months), similarly to the results of an earlier study with SCLC patients [26]. This difference can result from the tumor types; MST from the start of DDW-consumption was 74.5 months in the adenocarcinoma subgroup, where females dominated (66.3\%), and 17.4 months in the squamous cell carcinoma subgroup, where the majority of patients $(76.5 \%)$ were male (Table 1). However, the gender difference existed also within one tumor type, as shown by data in Table 2 , so explanation by the tumor type can be only partial. An alternative explanation for the gender difference can be the different response of oncogenes to DDW in female and male mice [20]. But overall, MST in both genders was longer than the generally observed 10-12 months [6].

MST for patients in various stages of cancer at the beginning of DDW-consumption was significantly different (Table 3), which showed clearly that the earlier is the stage when patients start DDW-consumption, the longer is MST.

In the light of scientific evidence on anticancer effect of deuterium depletion [9, 21, 31, 33-35], an important aim is to find the best combination of DDW's application and conventional therapy. MST was calculated for the subgroups set up according to conventional therapies (surgery, chemotherapy, radiotherapy, and their combinations; Table 4). Surgery has an important role in survival. In group A (early stage), $95 \%$ and in group B, $27.7 \%$ of the patients underwent operation (Table 3), and their MST was 126.6 months and 48.3 months, respectively, calculated from the start of DDW-consumption. For patients who underwent surgery plus chemotherapy, we could not calculate MST because of the low death rate, which indicated the high efficiency of DDW and chemotherapy in combination.

The observed positive correlation between length of DDWconsumption and survival ( $r=0.667)$ (Figure 3 ) was another argument for the anticancer effect of DDW in the NSCLC patients.

The results show markedly longer survivals compared to prospective clinical data [2-6] for advanced lung cancer patients. This observation suggests that D-depletion in addition to conventional treatments prolongs survival at an advanced stage more efficiently than any targeted or combined therapy to date.

For the NSCLC patients involved, DDW-consumption provided additional benefits and played a significant role in preventing and/or delaying progression. Patients with longer DDW-consumption had a better MST.

Oral DDW treatment is safe and innocuous, preclinical toxicology studies [36], as well as prospective and retrospective clinical trials [24-27] confirmed that no adverse effects or unwanted events occurred during longterm application of DDW at a wide concentration range of 125 to 25 ppm.

In contrast to earlier reports on the inhibitory effect of deuterium-depleted media on different cell lines in vitro $[9,15,16,18,31]$, the highly accurate xCELLigence RTCA system was applied. Our data showed strong negative correlation between $\mathrm{D}$-concentration of the media and the growth of A549 cells, up to complete inhibition at 40 ppm. The most striking observation was that in case of gradually decreasing D-concentration in the medium every 8 hours, even 1 ppm decrease resulted in reduced growth rate compared to the control. When the D-level was decreased in $2.5 \mathrm{ppm}$ or 5 ppm steps, the inhibitory effect was higher $(2.5 \mathrm{ppm})$ or complete $(5 \mathrm{ppm})$. These data indicated the sensitivity of the investigated cells to actual $\mathrm{D}$ concentration and confirmed earlier findings describing strong influence of D-level on cell metabolism, leading to induction of apoptosis [9, 15, 18, 31, 32]. The data of this in vitro model were also in line with the clinical observations that DDW-consumption extended progression-free interval of breast and lung cancer patients $[25,26]$ and prevented relapse, since at least $1 \mathrm{ppm}$ decrease of $\mathrm{D}$ concentration can be achieved day-by-day when a human begins regular daily consumption of 1.5-2 liters of DDW with 105 ppm D-content. (Consumption of DDW with a certain $\mathrm{D}$ concentration leads to equilibrium, and in order to maintain continuous decrease of $D$ concentration it is recommended to change for DDW of 20 ppm lower D-level in every 2-3 months.) The inhibitory effect of DDW on tumor cell migration, observed in vitro in the present study, may also be of importance in MST lengthening and relapse 
prevention described in cancer patients consuming DDW $[24,27]$.

\section{Conclusion}

We conclude that D-depletion may offer additional benefits to conventional therapies and can be integrated into standard treatment regimens for NSCLC. In addition, in spite of the obvious limitations of the retrospective approach, our data may contribute to the assessment of the necessity and feasibility of prospective studies.

\section{Funding}

This work was sponsored by HYD LLC for Cancer Research and Drug Development.

\section{Declaration of conflicting interests}

The authors declare no conflict of interest.

\section{References}

[1] Siegel RL, Miller KD, Jemal A. Cancer statistics. CA Cancer J Clin. 2018; 68(1):7-30.

[2] Hirsch FR, Sequist LV, Gore I, Mooradian M, Simon G, et al. Long-term safety and survival with gefitinib in select patients with advanced non-small cell lung cancer: Results from the US IRESSA Clinical Access Program (ICAP). Cancer. 2018; 124(11):2407-2414.

[3] Abbasi S, Badheeb A. Prognostic factors in advanced non-small-cell lung cancer patients: Patient characteristics and type of chemotherapy. Lung Cancer Int. 2011; 2011:152125.

[4] Tas F, Ciftci R, Kilic L, Karabulut S. Age is a prognostic factor affecting survival in lung cancer patients. Oncology Letters. 2013; 6(5):15071513.

[5] Goldstraw P, Chansky K, CrowleyJ, Rami-Porta R, Asamura H, Eberhardt WEE, Nicholson AG, Groome P, Mitchell A, Bolejack V. The IASLC lung cancer staging project: Proposals for revision of the tnm stage groupings in the forthcoming (Eighth) Edition of the TNM classification for lung cancer. Journal of Thoracic Oncology. 2015; 11(1):39-51.

[6] Goffin J, Lacchetti C, Ellis PM, Ung YC, Evans WK. lung cancer disease site group of cancer care ontario's program in evidence-based care: First-line systemic chemotherapy in the treatment of advanced nonsmall cell lung cancer: a systematic review. J Thorac Oncol. 2010; 5(2):260-274.

[7] Inoue A, Kobayashi K, Maemondo M, Sugawara S, Oizumi S, et al. Updated overall survival results from a randomized phase III trial comparing gefitinib with carboplatin-paclitaxel for chemo-naive nonsmall cell lung cancer with sensitive EGFR gene mutations (NEJ002). Ann Oncol. 2013; 24(1):54-59.

[8] Zhiqiang G, Baohui $H$, Huimin W, Chunlei S, Liwen $X$, et al.. Clinical observation of gefitinib as a first-line therapy in sixty-eight patients with advanced NSCLC. Oncol Lett. 2012; 3(5):1064-1068.

[9] Somlyai G, Jancsó G, Jákli G, Vass K, Barna B, et al. Naturally occurring deuterium is essential for the normal growth rate of cells. FEBS Lett. 1993; 317(1-2):1-4.

[10] Katz JJ, Crespi HL. Isotope effects in biological systems. In Isotope Effects in Chemical Reactions. Collins CJ, Bowman NS. Eds. Van Nostrand Reinhold: New York, USA, 1971. pp.286-363.

[11] Rundel PW, Ehleringer JR, Nagy KA. Stable Isotopes in Ecological Research. Springer: New York, USA; 1988.

[12] Jancsó G. Isotope effects. In Handbook of Nuclear Chemistry. Vértes A, Nagy S, Klencsár Z. Eds. Kluwer Academic Publishers: Dordrecht, Netherlands, 2003. pp.85-116.

[13] Enright J. Heavy water slows biological timing processes. Zeitschrift für vergleichende Physiologie. 1971; 72:1-16.

[14] Harvey EN. Biological effects of heavy water. The Biological Bulletin. 1934; 66(2):91-96.

[15] Somlyai G, Laskay G, Berkényi T, Jákli Gy, Jancsó G. Naturally occurring deuterium may have a central role in cell signaling. In Synthesis and Applications of Isotopically Labelled Compounds. Heys JR, Melillo D. Eds, John Wiley and Sons Ltd: New York, USA; 1998. pp.137-141.

[16] Yavari K, Kooshesh L. Deuterium depleted water inhibits the proliferation of human mcf7 breast cancer cell lines by inducing cell cycle arrest. Nutrition and Cancer. 2019; 71(6):1019-1029.

[17] Syroeshkin A, Levitskaya O, Uspenskaya E, Pleteneva T, Romaykina D, et al. Deuterium depleted water as an adjuvant in treatment of cancer. Sys Rev Pharm. 2019; 10(1):112-117.

[18] Zlatskiy IA, Zlatska AV, Antipova NV, Syroeshkin AV. Effect of deuterium on the morpho-functional characteristics of normal and cancer cells in vitro. Trace Elements and Electrolytes. 2018; 35(4):211-214.

[19] Somlyai G, Laskay G, Berkényi T, Galbács Z, Galbács G, et al. The biological effects of deuterium-depleted water a possible new tool in cancer therapy. Journal of Oncology. 1998; 30:91-94.

[20] Gyöngyi Z, Somlyai G. Deuterium depletion can decrease the expression of C-myc Ha-ras and p53 gene in carcinogen-treated mice. In Vivo. 2000; 14(3):437-439.

[21] Zhang X, Gaetani M, Chernobrovkin A, Zubarev RA. Anticancer effect of deuterium depleted water - Redox disbalance leads to oxidative stress. Mol Cell Proteomics. 2019; 18(12):2373-2387.

[22] Zhang $X$, Wang J, Zubarev RA. Slight deuterium enrichment in water acts as an antioxidant: is deuterium a cell growth regulator? Mol Cell Proteomics. 2020; 19(11):1790-1804.

[23] Boros LG, D'Agostino DP, Katz HE, Roth JP, Meuillet EJ, et al. Submolecular regulation of cell transformation by deuterium depleting water exchange reactions in the tricarboxylic acid substrate cycle. Med Hypotheses. 2016; 87:69-74.

[24] Kovács A, Guller I, Krempels K, Somlyai I, Jánosi I, et al. Deuterium depletion may delay the progression of prostate cancer. J Cancer Ther. 2011; 2(4):548-556.

[25] Krempels K, Somlyai I, Gyöngyi Z, Ember I, Balog K, et al. A retrospective study of survival in breast cancer patients undergoing deuterium depletion in addition to conventional therapies. J Cancer Res Ther. 2013; 1(8):194-200.

[26] Gyöngyi Z, Budán F, Szabó I, Ember I, Kiss I, et al. Deuterium depleted water effects on survival of lung cancer patients and expression of Kras, $\mathrm{Bcl} 2$, and Myc Genes in mouse lung. Nutr Cancer. 2013; 65(2):240-246.

[27] Krempels K, Somlyai I, Somlyai G. A retrospective evaluation of the effects of deuterium depleted water consumption on 4 patients with brain metastases from lung cancer. Integr. Cancer. Ther. 2008; 7(3):172-181.

[28] London H. Separation of isotopes. George Newnes Limited: London, England; 1961.

[29] Martinez-Serra J, Gutierrez A, Muñoz-Capó S, Navarro-Palou M, Ros T, et al. xCELLigence system for real-time label-free monitoring of growth and viability of cell lines from hematological malignancies. Onco Targets Ther. 2014; 7:985-994.

[30] Chen VW, Ruiz BA, Hsieh M, Wu CW, Ries L, et al. Analysis of stage and clinical/prognostic factors for lung cancer from SEER registries: AJCC staging and collaborative stage data collection system. Cancer. 2014; 120 (0 0):3781-3792.

[31] Cong FS, Zhang YR, Sheng HC, Ao ZH, Zhang SY, et al. Deuteriumdepleted water inhibits human lung carcinoma cell growth by apoptosis. Exp Ther Med. 2010; 1(2):277.

[32] Somlyai G, Molnár M, Laskay G, Szabó M, Berkényi T, et al. Biological significance of naturally occurring deuterium: the antitumor effect of deuterium depletion. Orv Hetil. 2010; 151(36):1455-1460.

[33] Kamal Y, Lida K. Deuterium depleted water inhibits the proliferation of human mcf7 breast cancer cell lines by inducing cell cycle arrest. Nutrition and Cancer. 2019; 71(6):1019-1029.

[34] Dominic AS, Shoemaker RH, Paul KD, Monks A, Tierney S, et al. Evaluation of a soluble tetrazolium/formazan assay for cell growth and drugsensitivity in culture using human and other tumor cell Lines. Cancer Res. 1988; 48(17):4827-4833.

[35] Siniak IE, Turusov VS, Grigoriev Al, Zaridze DG, Gaidadymov VB, et al. Consideration of the deuterium-free water supply to an expedition to mars. Aerospace and Environmental Medicine. 2003; 37(6):60-63.

[36] Török G, Csík M, Pintér A. Effects of different deuterium concentrations of the media on the bacterial growth and mutagenesis. Egészségtudomány/Health Science. 2000; 44:331. 